\title{
ANALISIS KESALAHAN PENGGUNAAN KATA KERJA BERATURAN DAN TIDAK BERATURAN PADA KARANGAN NARASI
}

\author{
Susilawati, Muhammad Sulhan \\ Program Studi Pendidikan Bahasa Inggris, Fakultas Bahasa dan Seni \\ Universitas Indraprasta PGRI \\ susiwati512@gmail.com; m.sulhan20@yahoo.com
}

\begin{abstract}
Abstrak
Tujuan dari penelitian adalah untuk menganalisis kesalahan penggunaan kata kerja beraturan dan tidak beraturan pada karangan narasi.Metode penelitian yang digunakan metode deskriptif kualitatif. Setelah menganalisiskesalahan dari 30 data karangan narasi yang dibuat oleh 30 siswa terdapat total kesalahan adalah 150, akhirnya penulis menarik simpulan bahwa kesalahan kata kerja tidak beraturan yaitu 108 kesalahan $(72 \%)$ dan kata kerja beraturan yaitu 42 kesalahan $(28 \%)$.
\end{abstract}

Kata Kunci: Analisis, Kesalahan, kata kerja beraturan, kata kerja tidak beraturan, karangan narasi

\begin{abstract}
The purpose of this study is to analyze the error of using regular and irregular verbs in the narrative text. Research method used in the research is descriptive qualitative method. After analyzing the errprs of 30 data made by 30 students, the total errors made are 150. It can be conclude that the irregular verbs error made are 108 or about $72 \%$ and the regular verb errors are 42 or about $28 \%$.
\end{abstract}

Key words: analyze, regular verb, irregular verb, narration text

\section{PENDAHULUAN}

Bahasa Inggris merupakan bahasa asing pertama yang dimasukan ke dalam kurikulum pengajaran di Indonesia. Namun mempelajari bahasa Inggris bukanlah hal yang mudah karena bahasa Inggris mempunyai tata bahasa yang berbeda dengan bahasa Indonesia. Meskipun demikian, perkembangan bahasa Inggris di tanah air telah mengalami perkembangan yang cukup baik. Sebagai contoh, dalam dunia pendidikan, bahasa Inggris merupakan salah satu mata pelajaran yang harus dikuasai oleh siswa. Bahasa Inggris diajarkan di sekolah-sekolah di seluruh Indonesia khususnya dijenjang Sekolah Menengah Pertama dan Sekolah
Menengah Atas. Bahasa Inggris juga merupakan salah satu mata pelajaran yang diujikan dalam ujian nasional. Selain sekolah formal, ada banyak lembaga kursus yang menawarkan jasa pengajaran bahasa Inggris.

Dalam mempelajari bahasa Inggris ada 4 keterampilan yang harus dimiliki oleh siswa yaitu berbicara (speaking), membaca (reading), menulis (writing), dan menyimak (listening).Salah satu keterampilan tersebut yaitu menulis (writing) dapat menolong siswa untuk mengembangkan pola pikir mereka. Kemampuan menulis bukanlah kemampuan yang turun temurun melainkan hasil belajar yang di dapat dengan cara berlatih bagaimana cara menulis dengan benar, sehingga pesan yang disampaikan dapat dimengerti oleh 
pembaca. Namun menulis bukan hal yang mudah, sehingga tidak jarang siswa melakukan kesalahan dalam menulis.Menulis disebut rumit karena siswa perlu mempelajari dari semua aspek penulisan dalam satu waktu.

Ada beberapa jenis karangan yaitu karangan narasi, karangan eksposisi, karangan deskripsi, karangan argumentasi, dan karangan persuasi. Namun, dalam hal ini penulis hanya meneliti tentang menulis dalam karangan narasi. Karangan narasi adalah suatu bentuk karangan yang berusaha menggambarkan dengan sejelas-jelasnya kepada pembaca tentang peristiwa pada suatu waktu, yaitu di masa lampau. Contohnya seperti cerita rakyat, biografi, dan lain sebagainya. Dalam membuat sebuah karangan, terutama dalam karangan narasi bahasa Inggris sangatlah penting memperhatikan tenses. Tenses bahasa Inggris terdiri dari 4 macam, yaitu present tense, past tense, future tense, dan past future tense. Namun, dalam karangan narasi, tenses yang digunakan hanyalah past tense karena past tense digunakan untuk menyatakan suatu kejadian/perbuatan yang terjadi pada waktu dimasa lampau dan tidak ada hubungannya dengan saat ini. Past tense sendiri memiliki perubahan kata kerja, yang terbagi atas 2 yaitu kata kerja beraturan (regular verb) dan kata kerja tidak beraturan (irregular verb), dalam hal ini lah siswa sering melakukan kesalahan penggunaan kata kerja, dan salah satu alasanya karena siswa malas dalam menghafal bentuk perubahan kata kerja tersebut. Oleh karena itu, penulis melatih dan menguji keterampilan menulis siswa dalam karangan narasi, agar siswa lebih menguasai tenses dalam bentuk past tense terutama dalam penggunaan kata kerja beraturan dan tidak beraturan. Dengan demikian diharapkan siswa dapat menyadari dan mengetahui kesalahan yang mereka buat, sehingga siswa dapat menulis dengan benar sesuai dengan tenses yang digunakan.

Berdasarkan alasan-alasan di atas, penulis tertarik untuk menganalisis tentang kesulitan yang timbul pada siswa dalam penggunaan kata kerja, baik kata kerja beraturan maupun tidak beraturan dalam karangan narasi. Penulis juga tertarik menganalisis kesalahan penggunaan kata kerja beraturan dan tidak beraturan dalam karangan narasi bahasa Inggris di kelas VIII SMPNurul Hikmah II Bekasi karena suasana pembelajaran di sekolah tersebut menyenangkan dan SMP tersebut juga tergolong sebagai sekolah baru dengan akreditasiA yang diharapkan siswa dapat fokus dalam pembelajaran bahasa Inggris.

Perlu diketahui bahwa sekolah SMP Islam Nurul Hikmah II merupakan sekolah dengan beasiswa gratis $(100 \%)$ yang didirikan pada tahun 2003 oleh Yayasan Da'wah Umahatul Muslimat Pondok Gede yang dibina oleh $\mathrm{Hj}$. Alia Munabari sebagai upaya tindak lanjut dari berdirinya TKA/TPA dan SDI Nurul Hikmah II yang telah berdiri tahun 1996 dan diresmikan oleh wakil mentri agama RI , Bapak Yusuf Thalib, SH. Sekolah ini dibangun atas misi untuk menyelamatkan anak - anak muslim usia sekolah lemah ilmu, dan ekonomi dan juga untuk melawan serangan kristenisasi yang marak dilancarkan khususnya di daerah kampung sawah Jatimelati, Pondok Melati - Bekasi dan sekitarnya.Meskipun sekolah dengan beasiswa $100 \%$, sekolah ini tetap memberikan kriteria peserta didik ketika dalam penerimaan siswa baru. Adapun kriteria calon peserta didik di sekolah ini antara lain: (1) Dari keluarga tidak mampu (2) Lulus tes seleksi. Adapun prosedur penerimaan peserta didik adalah sebagai berikut: (1) Orang tua siswa mendaftar ke sekolah (2) 
Wawancara orang tua calon siswa (3) Survei tempat tinggal orang tua calon siswa (4) Pengumuman calon siswayang berhak mengikuti tes (5) Pengumuman hasil tes.

Meskipun gratis, sekolah ini menyediakan sarana dan prasarana untuk kenyamanan proses belajar para peserta didik. Prasarana tersebut antara lain, ruang kelas berjumlah 6 ruang, lab ibadah 1 ruang, lab IPA 1 ruang, dan perpustakaan 1 ruang. Adapun rombongan belajar (rombel) terdiri dari 6 rombel, masing - masing 2 kelas (VII, VIII, dan IX) dengan kelas terpisah antara laki-laki dan perempuan. Masing - masing rombel dapat diuraikan sebagai berikut: kelasVII terdiri dari 33 orang siswa laki-laki dan 36 orang siswa perempuan. Kelas VIII terdiri dari 30 orang siswa laki-laki dan 29 orang siswa perempuan. Kelas IX terdiri dari 18 orang siswa laki-laki dan 34 orang siswa perempuan.

Guru yang mengajar di sekolah tersebut berjumlah 11 orang, terdiri dari 7 orang perempuan dan 4 orang lakilaki.Adapun tenaga kependidikan (tendik) terdiri dari 3 orang, sedangkan PTK (guru ditambah tendik) di sekolah tersebut terdiri dari 14 orang.

\section{Hakikat Menulis}

Pengertian menulis menurut Gie (2002: 3) "Menulis adalah segenap rangkaian kegiatan seseorang mengungkapkan gagasan dan menyampaikannya melalui bahasa tulis kepada masyarakat pembaca untuk dipahami." Pengertian yang sama juga dijelaskan oleh Tarigan (2008: 22) "Menulis ialah menurunkan atau melukiskan lambang-lambang grafik yang menggambarkan suatu bahasa yang dipahami oleh seseorang, sehingga orang-orang lain dapat membaca lambang-lambang grafik tersebut kalau mereka memahami bahasa dan grafik itu." Selain itu, Tarigan (dalam Hasani, 2005: 1) juga mengemukakan bahwa "Menulis adalah salah satu jenis keterampilan berbahasa yang dimiliki dan digunakan oleh manusia sebagai alat komunikasi tidak langsung." Menurut Tarigan (2008: 1) "Keterampilan berbahasa mempunyai empat komponen, yaitu: keterampilan menyimak, keterampilan berbicara, keterampilan membaca dan keterampilan menulis." Harris (dalam Wibowo, 2001: 16) juga mengatakan "Kecakapan berbahasa memiliki empat unsur.Yakni, (a) kecakapan menyimak; (b) kecakapan berbicara; (c) kecakapan membaca; dan (d) kecakapan menulis."

Dalam memperoleh keterampilan atau kecakapan berbahasa, biasanya kita melalui suatu hubungan urutan yang teratur: mula-mula pada masa kecil kita belajar menyimak bahasa kemudian berbicara, sesudah itu kita belajar membaca dan menulis. Selanjutnya setiap keterampilan atau kecakapan itu erat pula berhubungan dengan prosesproses yang mendasari bahasa.Bahasa seseorang mencerminkan pikirannya. Semakin terampil atau cakap seseorang berbahasa, semakin cerah dan jelas pula jalan pikirannya.Keterampilan atau kecakapan hanya dapat diperoleh dan dikuasai dengan jalan praktek dan banyak latihan.Melatih keterampilan berbahasa berarti pula melatih berpikir. Morsey (dalam Wibowo, 2001: 17) mengungkapkan "Kecakapan menulis merupakan ciri-ciri orang atau bahasa yang terpelajar." Tulis-menulis digunakan oleh orang yang terpelajar untuk mencatat, merekam, meyakinkan, melaporkan, dan mempengaruhi orang lain. Aktivitas tersebut, tentu saja, hanya bisa dilakukan oleh mereka yang mampu menyusun pikirannya dan lalu mengutarakannya dengan jelas.Dan kejelasan ini, bertalian erat dengan pikiran, organisasi, pemakaian kata-kata, 
dan struktur kalimat.Aktivitas tersebut harus melalui latihan dan praktek yang gradual (berangsur-angsur), tekun, rajin, dan teratur. Kesimpulannya adalah dengan membiasakan sering melatih menulis terus menerus maka akan terlatih juga dalam penggunaan bahasa dan penambahan kosa katanya. Adapun beberapa manfaat dalam menulis menurut Leo (2010: 2) yaitu: "Membiasakan diri berpikir sistematis, membagikan keahlian, aktivitas yang menyehatkan, dan menghindarkan diri dari aktivitas negatif."

Dari tulisan di atas, dapat disimpulkan bahwa menulis adalah salah satu keterampilan atau kecakapan berbahasa yang memiliki banyak manfaat dan berbentuk komunikasi tidak langsung yang dilakukan oleh seseorang untuk mengungkapkan gagasan dalam bentuk bahasa tulis yang dapat dibaca dan dipahami oleh orang lain atau masyarakat.

\section{Hakikat Karangan}

Karangan adalah bentuk tulisan yang mengungkapkan pikiran dan perasaan dalam satu kesatuan tema yang utuh.Karangan diartikan pula dengan rangkaian hasil pikiran atau ungkapan perasaan ke dalam bentuk tulisan yang teratur.Karangan juga sangat berhubungan dengan bahasa.Di sekolah diberikan modal pengetahuan bahasa, bahkan dilatih untuk menggunakan kecakapan bahasa tersebut dalam menulis.Semua itu merupakan modal berharga yang harus dikembangkan lebih lanjut dalam kehidupan berbahasa yang sesungguhnya.Dalam masyarakat, mengarang tidak hanya dituntut pengetahuan teori saja melainkan prakteknya dalam tulis-menulis. Pada prinsipnya fungsi mengarang adalah sebagai alat komunikasi segala gagasan yang ingin disampaikan kepada orang lain. Selain itu, karangan dapat memudahkan kita merasakan dan menikmati hubungan-hubungan, memperdalam daya tanggap, memecahkan masalah yang dihadapi, dan menyusun urutan bagi pengalaman.

Pengertian dari mengarang juga dijelaskan oleh Gie (2002 : 3) yang menyatakan bahwa, "Mengarang adalah segenap rangkaian kegiatan seseorang mengungkapkan gagasan dan menyampaikannya melalui bahasa tulis kepada masyarakat pembaca untuk dipahami". Oleh karena itu, gagasan yang disampaikan harus dirangkaikan secara logis dan sistematis, dan perlu diperhatikannya kosakata dan tata kata yang tepat.Salah satunya dalam penulisan kata kerja.Karena dalam bahasa Inggris kata kerja sangat lah berpengaruh pada arti.Maka dianjurkan, untuk memperbanyak kosakata berbahasa dan latihan menulis dalam membuat karangan secara berulang.

Berdasarkan penjelasan di atas, maka mengarang adalah kemampuan seseorang untuk melahirkan ide yang akan disampaikan kepada orang lain melalui tulisan, dengan penggunaan tata bahasa dan kosakata yang tepat, yang bertujuan agar pembaca mengerti apa yang disampaikan.

\section{Hakikat Kesalahan Berbahasa}

Menurut Pranowo (2014: 118) "Kesalahan berbahasa adalah penyimpangan kaidah dalam pemakaian bahasa." Kesalahan berbahasa biasa dilakukan oleh pembelajar bahasa kedua atau bahasa asing. Menurut Corder (dalam Pranowo, 2014: 122) istilah dalam kesalahan dapat dibedakan menjadi 3, yaitu :

1. Mistake

Mistake adalah penyimpangan struktur lahir yang terjadi karena penutur tidak mampu menentukan pilihan penggunaan ungkapan yang tepat sesuai dengan situasi yang ada. 


\section{Lapses}

Lapses adalah penyimpangan bentuk lahir karena beralihnya pusat perhatian topik pembicaraan secara sesaat.Kesalahan berbahasa yang disebut 'selip' disebabkan oleh faktor non-lingual, seperti kelelahan, kehilangan konsentrasi, tergesa-gesa dan sebagainya.

3. Errors

Errors adalah penyimpangan bentuk lahir dari struktur baku yang terjadi karena pemakaian belum menguasai sepenuhnya kaidah bahasa.

\section{Hakikat Karangan Narasi}

Karangan Narasi menurut Semi (dalam Hasani, 2005: 24) "Karangan Narasi merupakan bentuk percakapan atau tulisan yang bertujuan menyampaikan atau menceritakan rangkaian peristiwa atau pengalaman manusia berdasarkan perkembangan dari waktu ke waktu." Pengertian yang sama dijelaskan oleh Keraf (dalam Hasani, 2005: 24) "Karangan narasi adalah suatu bentuk karangan yang berusaha menggambarkan dengan sejelas-jelasnya kepada pembaca tentang peristiwa pada suatu waktu." Karangan narasi juga dijelaskan oleh Keraf dalam bukunya Argumentasi dan Narasi (2000: 136) "Karangan narasi adalah suatu bentuk wacana yang berusaha menggambarkan dengan sejelas-jelasnya kepada pembaca suatu peristiwa yang telah terjadi”.

Ciri-ciri karangan narasi yaitu (1) berbentuk cerita tentang manusia, (2) menonjolkan pelaku, (3) terdapat perkembangan dari waktu ke waktu, dan (4) disususn secara sistematis. Hal yang sama juga dinyatakan oleh Keraf (2000: 136) bahwa ciri karangan narasi yaitu (1) menonjolkan unsur perbuatan atau tindakan, (2) dirangkai dalam urutan waktu, (3) berusaha menjawab pertanyaan, apa yang terjadi?, (4) ada konfliks. Intinya tujuan dari narasi ini mengatakan kepada pembaca tentang apa-apa yang terjadi.Dengan demikian, pokok permasalahan dalam narasi adalah perbuatan, tindakan, atau aksi.

Berdasarkan pengertianpengertian narasi di atas, dapat disimpulkan bahwa narasi adalah karangan yang menggambarkan peristiwa dalam rangkaian waktu tertentu.Melalui karangan ini, pembaca dibuat seolah-olah dapat merasakan peristiwa demi peristiwa yang terjadi.

\section{Hakikat Kata Kerja}

Dalam setiap kalimat bahasa Inggris harus mengandun sedikitnya satu subjek, satu kata kerja, dan satu objek, agar menjadi satu kesatuan kalimat yang benar. Seperti yang dikatakan oleh Siagian, dkk (2015: 63) "Subjek dan Predikat merupakan salah satu penentu kalimat.Apabila urutan kata dalam pernyataan itu tidak menunjukan adanya unsur subjek dan predikat secara jelas, pernyataan itu bukan kalimat melainkan berupa frase atau klausa." Dan pernyataan yang sama juga dinyatakan oleh "Hariyono dan Mc. Carthy (2008: 160) "Tanpa adanya kata kerja, apa yang ditulis akan bermakna sebagai suatu kelompok kata saja." Menurut Hariyono dan Mc. Carthy (2008: 160) "Verb (Kata Kerja) adalah kata yang menunjukkan suatu pekerjaan perbuatan, tingkah laku atau kegiatan." Dalam hakikat kata kerja ini, penulis hanya menulis tentang simple past tense, past perfect tense, kata kerja beraturan dan tidak beraturan (regular and irregular verb), dan passive voice (kalimat pasif), sesuai kaitannya dengan karangan narasi bahasa Inggris, yang penulis jadikan sebagai bahan penelitian. 


\section{METODE PENELITIAN}

Pendekatan penelitian yang digunakan dalam penelitian ini adalah pendekatan penelitian kualitatif dengan menggunakan metode deskriptif kualitatif.Penelitian yang bersifat deskriptif bertujuan menggambarkan secara tepat sifat individu, keadaan, gejala atau kelompok tertentu dalam masyarakat.Gejala yang dimaksud adalah data berupa kesalahan-kesalahan kata kerja beraturan dan tidak beraturan (regular and irregular verb) yang dibuat oleh siswa.Dalam penelitian ini metode yang digunakan adalah metode tertulis berupa karangan narasi Bahasa Inggris. Penulis juga memilih "One shot model". Menurut Arikunto (2013: 83) "One shot model yaitu model pendekatan yang menggunakan satu kali pengumpulan data pada suatu saat". Jadi, penulis melakukan penelitian ini dengan hanya menggunakan waktu 1 hari untuk penelitian langsung ke lokasi penelitian dan melakukan pengumpulan data penelitian dari siswa kelas VIII SMP Nurul Hikmah II Bekasi.

\section{HASIL DAN PEMBAHASAN}

Dalam penelitian ini penulis menjabarkan kesalahan-kesalahan penggunaan kata kerja beraturan dan tidak beraturan dalam karangan narasi bahasa Inggris siswa kelas VIII SMP Nurul Hikmah II Bekasi.Dari hasil analisis kesalahan, jumlah soal kata kerja yang diberikan masing-masing siswa dalam sebuah karangan narasi yaitu 50 soal.Berdasarkan penelitian tersebut, didapatkan data kesalahan penggunaan kata kerja beraturan dan tidak beraturan yang dilakukan oleh siswa dalam karangan narasi bahasa Inggris. Rumus yang digunakan penulis untuk menghitung persentase jenis kesalahan penggunaan kata kerja beraturan dan tidak beraturan, sebagai berikut :

$$
\frac{\text { Jumlah jenis kesalahan }}{\text { Jumlah seluruh kesalahan }} \times 100
$$

Tabel 1. Rekapitulasi Persentase Kesalahan

\begin{tabular}{lcc}
\hline \multirow{2}{*}{ Responden } & \multicolumn{2}{c}{ Klasifikasi Kesalahan } \\
\cline { 2 - 3 } & Regular Verb & Irregular Verb \\
\hline Siswa 1 & 3 & 2 \\
\hline Siswa 2 & 1 & 1 \\
\hline Siswa 3 & 4 & 2 \\
\hline Siswa 4 & 3 & - \\
\hline Siswa 5 & 2 & 2 \\
\hline Siswa 6 & 2 & - \\
\hline Siswa 7 & 2 & 3 \\
\hline Siswa 8 & 3 & 3 \\
\hline Siswa 9 & - & 2 \\
\hline Siswa 10 & 1 & 6 \\
\hline Siswa 11 & - & 9 \\
\hline Siswa 12 & 1 & 1 \\
\hline Siswa 13 & 2 & 3 \\
\hline Siswa 14 & 3 & 3 \\
\hline Siswa 15 & - & 5 \\
\hline Siswa 16 & - & 4 \\
\hline Siswa 17 & - & 3 \\
\hline
\end{tabular}




\begin{tabular}{lcc}
\hline Siswa 18 & - & 2 \\
\hline Siswa 19 & 1 & 4 \\
\hline Siswa 20 & - & 4 \\
\hline Siswa 21 & - & 4 \\
\hline Siswa 22 & - & 5 \\
\hline Siswa 23 & 2 & 3 \\
\hline Siswa 24 & - & 4 \\
\hline Siswa 25 & 3 & 7 \\
\hline Siswa 26 & 4 & 2 \\
\hline Siswa 27 & - & 6 \\
\hline Siswa 28 & - & 6 \\
\hline Siswa 29 & 2 & 7 \\
\hline Siswa 30 & 3 & 5 \\
\hline Total & $\mathbf{4 2}$ & $\mathbf{1 0 8}$ \\
\hline Persentase & $\mathbf{2 8 \%}$ &
\end{tabular}

Berdasarkan keterangan tersebut terlihat jelas bahwa siswa paling banyak melakukan kesalahan pada irregular verb (kata kerja tidak beraturan) yaitu 108 kesalahan dengan nilai persentase sebesar $72 \%$, dan kesalahan paling sedikit ada pada jenis kesalahan regular verb (kata kerja beraturan) yaitu 42 kesalahan dengan persentase sebesar $28 \%$.

Berikut disajikan jumlah kesalahan siswa kelas VIII SMP Nurul Hikmah II Bekasi.dalam bentuk diagram pie untuk memudahkan pemahaman bagi para pembaca.

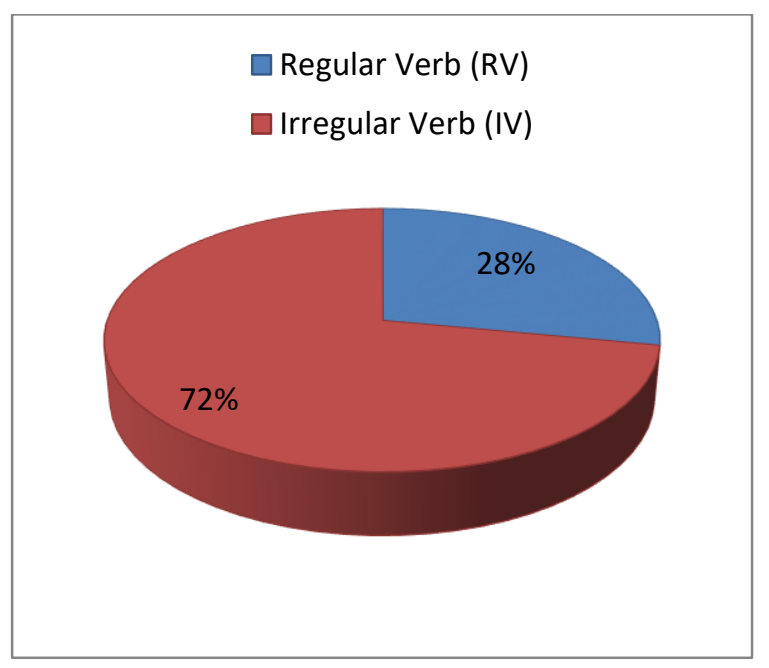

Berdasarkan hasil analisis yang telah dilakukan oleh penulis, maka didapatkan hasil yang menunjukkan bahwa siswa kelas VIII SMP Nurul Hikmah II Bekasi.masih banyak melakukan kesalahan dalam menggunakan kata kerja beraturan (regular verb) dan kata kerja tidak beraturan (irregular Verb) dalam menulis karangan narasi Bahasa Inggris.

Dalam hal ini jenis kesalahan pada kata kerja tidak beraturan (irregular Verb) menjadi kesalahan dengan jumlah tertinggi yaitu sebanyak 108 kesalahan atau $72 \%$, kesalahan ini banyak dilakukan oleh siswa karena faktor kurangnya pengetahuan siswa terhadap perubahan kata kerja tidak beraturan yang benar. Klasifikasi kesalahan terendah yaitu kata kerja beraturan (regular verb) sebanyak 42 kesalahan atau $28 \%$, kesalahan ini banyak disebabkan oleh siswa yang salah dalam menggandakan huruf.

Dari uraian kesalahan-kesalahan siswa tersebut dapat dilihat bahwa masih banyak siswa kelas VIII SMP Nurul Hikmah II Bekasi.yang melakukan kesalahan.Oleh karena itu, diharapkan para guru dapat memberikan materi pembelajaran yang lebih komunikatif dan membuat siswa lebih aktif dan kreatif, sehingga siswa lebih mudah dalam memahami materi yang 
dijelaskan.Selain dari itu, guru juga harus mengevaluasi kesalahankesalahan yang dibuat oleh siswa, sehingga kesalahan tersebut tidak terulang lagi.

\section{SIMPULAN}

Berdasarkan tujuan penelitian dan kajian analisis kesalahan terhadap karangan narasi Bahasa Inggris siswa kelas VII SMP Nurul Hikmah Bekasi, simpulan beberapa hal berkaitan dengan kesalahan yang dibuat oleh siswa tersebut yaitu :

1. Kesalahan yang paling banyak dilakukan oleh siswa adalah irregular verb (kata kerja tidak beraturan) yaitu sebanyak $72 \%$.

2. Kesalahan tertinggi pada irregular verb, yaitu karena siswa belum memahami perubahan kata kerja yang dapat diubah dari bentuk kata kerja pertama, bentuk kedua (past), hingga bentuk kata kerja ketiga (participle), sehingga kata kerja tidak beraturan yang dituliskan oleh siswa menjadi tidak sesuai. Dalam hal ini, khususnya kata kerja tidak beraturan masih sangat membutuhkan pemahaman lebih untuk mengetahui bentuk perubahan kata kerjanya.

3. Kesalahan penulisan dan pemilihan kata dapat disebabkan oleh minimnya pengetahuan akan kosakata karena peserta didik kurang membiasakan diri membaca kamus. Selain itu, pengucapan dalam Bahasa Inggris dan Bahasa Indonesia juga berbeda. Pengucapan Bahasa Inggris berbeda dengan penulisannya dan kata kerja yang digunakan disesuaikan dengan tenses yang sedang digunakan, sedangkan pengucapan dalam Bahasa Indonesia sama dan tidak mengenal tenses. Sebab perbedaan itulah, sehingga saat siswa menggunakan kata kerja bahasa Inggris dalam proses belajar, siswa hanya mengetahui bentuk kata kerja kerja dasar (infinitive verb) saja tanpa memahami tenses yang digunakan.

Berdasarkan fakta adanya kesalahan siswa dalam karangan narasi Bahasa Inggris, maka guru sebagai pentransfer ilmu harus memperhatikan permasalahan ini terutama untuk kesalahan kata kerja, baik kata kerja beraturan maupun kata kerja tidak beraturan berdasarkan tenses yang sesuai, karena apabila dibiarkan maka akan menimbulkan dampak atau pengaruh pada penguasaan bahasa yang lemah, serta kekeliruan terhadap struktur bahasa kedua bagi para siswa.

\section{DAFTAR PUSTAKA}

Arikunto, S. (2013). Prosedur Penelitian: Suatu Pendekatan Praktik. Jakarta: Rineka Cipta.

Gie, T.L. (2002). Terampil Mengarang. Yogyakarta: Andi.

Hariyono, R., \& Carthy, M.A. (2008). $A B C$ Plus English Grammar: Complete Edition. Surabaya: Gitamedia Press.

Hasani, A. (2005). Ihwal Menulis. Banten: Untirta Press.

Keraf, G. (2000). Argumentasi dan Narasi. Jakarta: Gramedia.

Leo, S. (2010). Kiat Jitu Menulis dan Menerbitkan Buku. Jakarta: Erlangga.

Pranowo. (2014). Teori Belajar Bahasa: Untuk Guru Bahasa dan Mahasiswa Jurusan Bahasa. Yogyakarta: Pustaka Pelajar.

Siagian, I, dkk. (2015). Bahasa Indonesia: Program Studi Bahasa Inggris. Jakarta: Unindra Press. 
Tarigan, H.G. (2008). Membaca: Sebagai Suatu Keterampilan Berbahasa. Bandung: Angkasa. . (2008). Menulis: Sebagai Suatu Keterampilan Berbahasa. Bandung: Angkasa.

Tarigan, H. G., \& Tarigan. D. (2011). Pengajaran Analisis Kesalahan Berbahasa. Bandung: Angkasa.
Wibowo, W. (2001). Manajemen Bahasa: Pengorganisasian Karangan Pragmatik dalam Bahasa Indonesia Untuk Mahasiswa dan Praktisi Bisnis. Jakarta: Gramedia Pustaka Utama. 